原著論文

\title{
煎餅の咀嚼回数を指標とした咀嚼能力評価法による義歯装着効果の評価
}

本間 済 河野 正司 櫻井 直樹 小林 博

\section{Evaluation of Prosthetic Treatment Using Number of Chewing Strokes until Swallowing of Water Absorbing Rice Crackers}

Honma Wataru, Kohno Shoji, Sakurai Naoki and Kobayashi Hiroshi

\section{歯科補緅学的意義}

今までに開発されてきた咀嚼能力の評価方法は，その大半が粉砕能力の評価を主体としたもので，煩雑であった？そ こで, 本研究ではまず目視による咀嚼回数計測の的中度を検討し, 次に大学病院においてメンテナンスに移行した義 歯装着者の補経治療効果の評価を試みた，本評価法は，損形態別の義歯装着効果の評価が可能であった．また，咀 鲅回数の改善率を用いた分析を行うことにより，義歯機能状態の評価が可能であることが示唆された.

\section{抄 録}

目的：これまで種々行われてきた咀嚼能力の評価方法は，その大半が粉砕能力評価を主体とした評価法 であった. そこで，咀嚼能力を簡易に評価できる方法を用いて，義歯の咀嚼能力評価を試みた。

方法：被倹者は，大学病院において一連の補綴治療が終了してメンテナンスに移行した義歯装着者 125 名（男性 71 名, 女性 54 名, 平均年齢 $70.4 \pm 15.5$ 歳）とした。咀嚼回数計測法（吸水性の高い煎餅を 用いて初回嚥下までの咀嚼回数を計測する方法）を用い，各被検者をアイヒナーの欠損分類で群分けし て, 義歯補緅治療効果の検討を行った.

結果 : 事前に行った筋電図，喉頭運動および嚥下音より明確となる初回嚥下までの咀嚼回数の的中度が 高いことを確認後，義歯の装着効果の評価を行い以下の結果を得た. 1. 義歯非装着時の咀嚼回数にアイ ヒナー A 群, B 群, C 群間で有意差が認められた. 2. 義歯装着時の咀嚼回数にアイヒナー A 群, B 群, C 群間で有意差は認められなかった． 3．義歯の装着により咀嚼回数の有意な減少が認められた４．ア イヒナー A 群， B 群，C 群の順に咬合支持域数が減少するに伴い，被検者それぞれで異なる初回唬下 までの咀嚼回数で除した值である咀嚼回数の改善率が有意に大きくなった。

結論 : 本評価法は，欠損形態別の義歯装着効果の評価が可能であった．また，咀嚼回数の改善率を用い た分析を行うことにより，義歯機能状態の評価が可能であることが示唆された.

和文キーワード

咀嚼回数, 咀嚼能力, 義歯装着効果, 咀嚼回数の改善率

新潟大学大学院医歯学総合研究科攖食機能再建学分野

Division of Removable Prosthodontics, Niigata University Graduate School of Medical and Dental Sciences 受付 : 2005 年 1 月 13 日 / 受理 $: 2005$ 年 12 月 27 日

Received on January 13, 2005/Accepted on December 27, 2005 


\section{I. 緒 言}

加齢に伴い欠損歯数は増加することから，高齢社会 となった我が国では，多くの高齢者が多数歯欠損状態 となっており，歯科補緅治療を受けている ${ }^{11}$ 。この補 緅治療によって咬合が形態的に回復された場合に，機 能的な面が同時に回復されていることが当然求められ てくる.

すなわち，エヴィデンスに基づいた補緅治療を遂行 するには装着された補緅装置によってどの程度機能回 復しているかの正しい評価が不可欠である.

今までに開発されてきた咀嚼能力評価法は，咀嚼試 料の粉砕粒子の分布状態を判定する篩分法 ${ }^{2.3)}$ や咀嚼 試料の内容物を判定するグミゼリー法 ${ }^{4)}$, ATP 顆粒 吸光度法 ${ }^{5)}$ が報告されている。 また, 混合能力評価 を主とした方法としては，チューインガム ${ }^{6)}$ やワッ クス7)を用いた方法が報告されている。これに対し， 主観的方法として，質問表を用いて被検者の各種食品 の捸取状況から咀嚼能力を評価する方法 ${ }^{8)}$ が知られ ている.このほかに間接的な咀嚼能力評価法として筋 電図を用いる方法 ${ }^{9)}$ や顎運動を分析する方法 ${ }^{10)}$ ，嚥 下造影法（Videofluorography）の支援による食塊形 成能力を評価する方法 ${ }^{11)}$ など多岐にわたる.

\section{II. 研究方法}

本研究は新潟大学医歯学総合病院倫理委員会の承認 を受けて行った.

\section{1. 咀嚼回数計測法の的中度}

個性正常咬合をもつ成人男子を被検者として，被検 食品として特定の煎餅を自由咀嚼してもらい，筋電図 学的な初回嚥下までの咀嚼回数のデータと目視による 初回嚥下までの咀嚼回数のデータとの的中度を求め, 3 回試行による平均值を求めた.

\section{1）被検者}

被検者は，咀嚼および嚥下機能に異常を認めず個性 正常咬合を有する本学職員, 学生のボランティア成人 男子 5 名（平均年齢 $26.5 \pm 2.6$ 歳）とした。 なお， 5 名は全て唾液嚥下時の喉頭の動きを皮膚上から視診, 触診により判定可能であることを確認できた者であ る.
2）被検食品

食品は，煎餅（亀田製菓製，さくさくサラダせん， $49 \times 48 \times 8.8 \mathrm{~mm} ， 2.66 \mathrm{~g}$, 円板状）を用いた。この煎 餅は，唾液を吸収しやすく，食塊形成能力の評価が可 能と報告されている ${ }^{12)}$.

3）測定項目

図 1 に示す武川ら ${ }^{13)}$ に準じた方法で表面筋電図, 喉頭運動，嚥下音より苝下を認識し，表面筋電図によ り咀嚼回数を計測した。詳細は ${ }^{4)}$ 測定方法の項目に 後述する.

（1）喉頭運動：触診により嚥下時の甲状軟骨の動く 範囲を確認し，その最上部の皮虑上に小型圧力 センサ PS-1KC (共和電業社)をサージカルテー プにて貼付し測定した.

（2）嚥下音：コンタクトマイク JM0116（小野測器） を甲状軟骨の外側に両面テープにて貼付し測定 した.

（3）筋活動：片側の咬筋と顎二腹筋前腹から電極間 距離 $15 \mathrm{~mm}$ にて，表面電極（日本光電社製 NT -611U）により双極導出した，導出した筋活動 は筋電アンプ（日本光電社製 MGG-6100）を 用いて, 時定数: $0.03 \mathrm{sec}$, High-cut : $1 \mathrm{kHz}$ と して 2,000 倍に増幅した後, サーマルアレイコー ダ（日本光電社製 RTA-1300M）にて記録した。

4）測定方法

はじめに，水 $10 \mathrm{ml}$ を 1 回で讌下する運動を行わせ, 喉頭運動の測定に用いる小型圧力センサの貼付位置の 決定を行った．すなわち，武川ら ${ }^{13)}$ の方法に準じた 方法で記録紙上で, 安静時の波高が $1 \mathrm{~mm}$ 以下で, か つ水嚥下時の波高が $3 \mathrm{~mm}$ 以上になるように，センサ の貼付位置の微調整を行った。

初回嚥下までの咀嚼回数は, 初回嚥下時に被検者に 挙手で嚥下を知らせてもらい（認識嚥下），その時点 まで観察者が咀嚼の指標としてオトガイの動きを観察 することによって計測した。

5）分析方法

表面筋電図 (咀嚼回数), 小型圧力センサ (喉頭運動), コンタクトマイク (嚥下音) の導出データを, サーマ ルアレイコーダ（日本光電社製 RTA-1300M）で記録 し，武川ら ${ }^{13)}$ に準じた方法で初回嚥下までの咀嚼回 数を計測した.すなわち，喉頭運動に関しては，波高 が $1.5 \mathrm{~mm}$ 以上を示す場合を嚥下と判定，さらに波高 


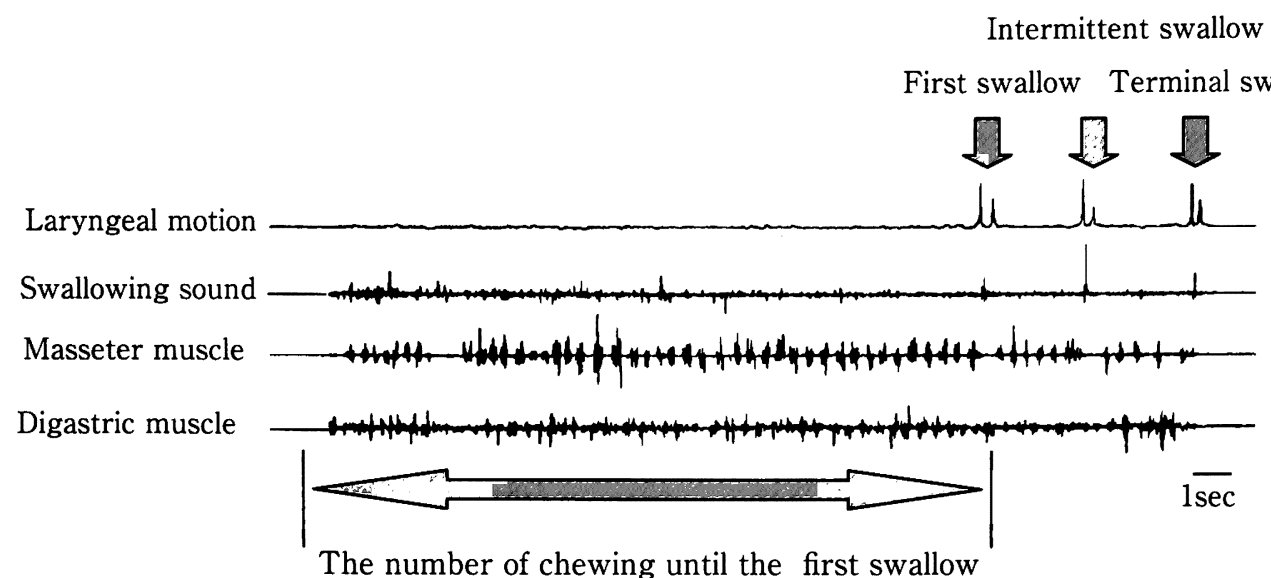

図 1 The observation on the number of chewing strokes and swallowing by EMG ,laryngeal motion and swallowing sound

咬筋と顎二腹筋の筋電図と喉頭運動，嚥下音による咀嚼回数と嚥下の観察

が $1.5 \mathrm{~mm}$ 未満であっても咀嚼時とは区別される波形 が認められること，䜩下音に関しては，咀嚼音が小さ くなったあとに大きい音が認められること，筋電図に 関しては，咬筋と顎二腹筋の活動が同期し，かつ持続 時間が咀嚼時よりも長い活動が認められること ${ }^{14)}$, 以上 3 つの基準を満たしている場合も嚥下と判定し た. また, 並行して同一被検者において観察者のオト ガイ部観察による咀嚼回数と被検者が初回嚥下時挙手 することによって明確となる初回嚥下までの咀嚼回数 を計測し、サーマルアレイコーダ上に記録された初回 嚥下までの咀嚼回数を基準として術者の目視による初 回嚥下までの咀嚼回数の的中度を以下の数式で求め た.

的中度 $=$ (観察者の目視による初回嚥下までの咀嚼 回数 / 筋電図による初回嚥下までの咀嚼回数）

\section{2. 義歯装着効果の評価}

大学病院義歯（入れ歯）診療室でメンテナンスに移 行した義歯装着者を被検者として義歯装着時と非装着 時に被検食品として特定の煎餅を自由咀嚼してもら い, 初回嚥下までの咀嚼回数を評価の指標として義歯 装着効果および咬合支持の影響を観察した。

1）被検者

対象は平成 16 年から 17 年に新潟大学医歯学総合病 院義歯（入れ歯）診療室を受診し，義歯新製後 3 只月 以上経過し、メンテナンスに移行した義歯装着患者 125 名（男性 71 名，女性 54 名，平均年齢 $70.4 \pm 15.5$
歳)とした.

被検者は，上下両顎，もしくは上下顎いずれかに可 撤性義歯を使用しており, 本研究の趣旨を説明して同 意が得られた者である.

2） 欠損様式による分類

被検者の欠損様式についてはアイヒナーの分類法 ${ }^{15)}$ でクラス分けし，それぞれについて分析を行った．対 象となったアイヒナーA 群は 20 名, B 群は 76 名, C 群は 29 名である.

3）咀嚼能力評価法

今回使用した評価法は, 煎餅を咀嚼してもらい, そ の初回嚥下までの咀嚼回数を計測することによって咀 嚼能力を評価する方法である，この方法によると，食 塊形成能力に大きく関与する因子である唾液分泌量と 舌側貯留率の 2 つ因子と関連した咀嚼能力の評価が 可能であることが明らかになっている ${ }^{12)}$.

（1）被検食品

的中度の判定で用いた食品と同様の煎餅（亀田製菓 製、さくさくサラダせん）を用いた。

(2) 咀嚼回数の計測法

煎餅を半分に割り, 半円形 2 枚として被検者に咀嚼 してもらった. 被検者には煎餅を咀嚼側の制限を与え ず, 自由に咀嚼させ, 被検者自身が初回嚥下したと感 じた時を挙手により合図してもらい，それまでに要し た咀翾回数を測定した。

本実験においては, 初回嚥下までの咀嚼回数は, 初 回嚥下時に被検者に挙手で嶼下を知らせてもらい, そ 
の時点まで同一術者が咀嚼の指標としてオトガイの動 きを観察することにより計測した.

4）義歯補緅治療効果の評価

咀䍛実験は, 最初に義歯非装着時の状態で咀嚼回数 を計測後，食塊をすべて嚥下させ，食片の残留がなく なるように水で含嗽させた，その後，義歯を装着して もらい, 同様の咀䍛回数計測を行った。

義歯装着による咀嚼回数の変化から義歯装着の効果 を評価するため, 以下の評価項目を設定した.

まず，義歯装着時と非装着時の咀嚼回数の差を回数 差として求めた。 また，咀嚼回数は個人間で相違が認 められるため, 義歯非装着時の咀嚼回数に対する回数 差の割合を改善率として以下の数式を求め, 相対評価 を行った.

回数差 $=$ 義歯非装着時咀嚼回数 - 義歯装着時咀嚼回数 (回)

改善率 $=($ 回数差 $/$ 義歯非装着時咀嚼回数 $) \times 100(\%)$

5) 統計学的手法

関連 2 群の差の検定には条件に応じて paired t-test もしくは Wilcoxon signed rank testを用いた. 独立 多群の差の検定には条件に応じて一元配置分散分析も しくは Kruskal-Wallis testを用い, post-hoc test とし て Scheffe 法を用いた。なお，有意水準は $\alpha=0.05$ と した. 統計計算処理は StatView.ver5.0 (ABACUS, Concept 社製，米国）により行った.

\section{III. 結 果}

\section{1. 咀嚼回数計測法の的中度}

表 1 に示すように，咬筋と顎二腹筋の筋電図と喉頭 運動および嚥下音から，明確となる初回嚥下までの咀 嚼回数と, 術者のオトガイ部観察および被検者に挙手 してもらうことによって明確となる初回嬿下までの咀 嚼回数との的中度は $0.98 \pm 0.02$ であった.

\section{2. 義歯装着の効果について}

1）義歯非装着時咀嚼回数

アイヒナー分類ごとに義歯非装着時咀嚼回数を検討 すると, A 群では平均 $43.9 \pm 14.7$ 回, B 群では平均 $48.1 \pm 18.8$ 回, C 群では平均 $58.0 \pm 22.7$ 回で, 一元 配置分散分析で有意差を認め, 多重比較検定にてアイ ヒナーA 群と C 群間で $5 \%$ 以下の危険率で有意差を
表 1 The predictive value of the number of chewing stroke 咀嚼回数の的中度

$\mathrm{n}=3$

\begin{tabular}{cc}
\hline \hline Subject & Predictive value \\
\hline A & $0.95 \pm 0.05$ \\
B & $0.99 \pm 0.02$ \\
C & $0.99 \pm 0.02$ \\
D & $1.0 \pm 0.0$ \\
E & $0.97 \pm 0.01$ \\
\hline Total & $0.98 \pm 0.02$ \\
\hline
\end{tabular}

表 2 Number of chewing strokes with and without denture in subjects based on Eichner' s classifications 咀嚼回数の的中度

\begin{tabular}{lccccc}
\hline & & Without & With & $\begin{array}{l}\text { Significance of } \\
\text { without-with difference } \\
\text { Wilcoxon signed-ranks test }\end{array}$ \\
\hline A group & 20 & $43.9 \pm 14.7$ & $35.6 \pm 15.1$ & $\mathrm{p}=0.0011$ \\
\hline B group & 76 & $48.1 \pm 18.8 *$ & $34.7 \pm 13.6$ & $\mathrm{p}<0.0001$ \\
\hline C group & 29 & $58.0 \pm 22.7$ & $37.7 \pm 11.8$ & $\mathrm{p}<0.0001$ \\
\hline ANOVA & & $\mathrm{p}=0.0235$ & $\mathrm{p}=0.5914$ & \\
\hline Total & 125 & $49.7 \pm 19.6$ & $35.5 \pm 13.4$ & $\mathrm{p}<0.0001$ \\
\hline
\end{tabular}

認めた（表 2).

2）義歯装着時咀嚼回数

アイヒナー分類ごとに義歯装着時咀嚼回数を検討す ると, A 群では平均 $35.6 \pm 15.1$ 回, B 群では平均 $34.7 \pm 13.6$ 回, C 群では平均 $37.7 \pm 11.8$ 回で, 3 群 間で有意差を認めなかった（表 2)

3) 回数差

全被検者 125 名中 120 名の被検者は義歯使用により， 初回嚥下までの咀嚼回数が減少した. しかし, 義歯装 着によって咀嚼回数が増加した被検者は 3 名（アイヒ ナーA2 群, $\mathrm{A} 3$ 群, $\mathrm{B} 1$ 群の各 1 名), 変化しない被 検者が 2 名（アイヒナー A2 群, B1 群の各 1 名）存 在した (表 3).

（1）アイヒナー 3 群における評価值

アイヒナー分類ごとに回数差を検討すると，A 群 では平均 $8.4 \pm 9.8$ 回, B 群では平均 $13.4 \pm 11.7$ 回, C 群では平均 $20.3 \pm 15.1$ 回で, 一元配置分散分析で 有意差を認め, 多重比較検定にてアイヒナー A 群と $\mathrm{C}$ 群間で危険率 $1 \%$ 以下， B 群と C 群間で危険率 $5 \%$ 以下で有意差を認めた。 また, Wilcoxon signed rank 
表 3 Difference of chewing strokes in the subjects based on the Eichner's classifications アイヒナー分類別の回数差

\begin{tabular}{|c|c|c|c|}
\hline \multicolumn{2}{|c|}{ Classifications } & \multicolumn{2}{|l|}{ Full classifications } \\
\hline \multirow{2}{*}{$\begin{array}{l}\text { A group } \\
(n=20)\end{array}$} & \multirow[t]{2}{*}{$8.4 \pm 9.8$} & A2 group $(n=16)$ & $10.1 \pm 9.8$ \\
\hline & & A3 group $(n=4)$ & $1.5 \pm 6.6$ \\
\hline \multirow{4}{*}{$\begin{array}{l}\text { B group } \\
(n=76)\end{array}$} & \multirow{4}{*}{$13.4 \pm 11.7 \stackrel{* *}{*}$} & B 1 group $(n=17)$ & $6.5 \pm 10.4$ \\
\hline & & B2 group $(n=17)$ & $11.2 \pm 8.7$ \\
\hline & & B3 group $(n=20)$ & $16.2 \pm 10.5$ \\
\hline & & B 4 group $(n=22)$ & $18.0 \pm 13.3$ \\
\hline \multirow{3}{*}{$\begin{array}{l}C \text { group } \\
(n=29)\end{array}$} & \multirow{3}{*}{$20.3 \pm 15.1 \beth$} & C1 group $(n=10)$ & $23.4 \pm 17.2$ \\
\hline & & C2 group $(n=15)$ & $18.2 \pm 15.2$ \\
\hline & & C 3 group $(n=4)$ & $20.3 \pm 9.9$ \\
\hline Total & & $\mathrm{n}=125$ & $14.2 \pm 12.8$ \\
\hline ANOVA & $\mathrm{p}=0.0034$ & & $\mathrm{p}=0.0016$ \\
\hline
\end{tabular}

test によりアイヒナー $\mathrm{A}$ 群 $(\mathrm{p}=0.0011), \mathrm{B}$ 群 $(\mathrm{p}$ $<0.0001), C$ 群 $(\mathrm{p}<0.0001)$ 全ての群において咀 嚼回数が義歯装着により有意に減少し，咬合支持域数 が減少するのに従って，義歯装着による咀嚼回数の減 少傾向を認めた.

（2）アイヒナー詳細分類における評価値

アイヒナー詳細分類別の回数差については，一元配 置分散分析で有意差を認めた，平均值の比較により， アイヒナー $\mathrm{A} 3<\mathrm{B} 1<\mathrm{A} 2<\mathrm{B} 2<\mathrm{B} 3<\mathrm{B} 4<\mathrm{C} 2<$ $\mathrm{C} 3<\mathrm{C} 1$ の順で回数差の増加傾向が認められた.

4) 改善率

（1）アイヒナー 3 群における評価値

回数差を義歯非装着時咀嚼回数で除することによっ て標準化し，改善率として分析した全被検者の值を表 4 に示す.

アイヒナー分類別にみると，A 群では，義歯装着 による咀嚼回数の改善率は平均 $19.1 \pm 16.6 \%, B$ 群 では平均 $25.4 \pm 16.4 \%, \mathrm{C}$ 群では平均 $32.1 \pm 15.0 \%$ で, 一元配置分散分析で有意差を認め, 多重比較検定にて アイヒナーA 群と C 群間で危険率 $5 \%$ 以下で有意差 を認めた。

(2) アイヒナー詳細分類における評価値

アイヒナーの詳細分類別の改善率については，一元 配置分散分析で有意差を認めた. 平均值の比較により, $\mathrm{A} 3<\mathrm{B} 1<\mathrm{A} 2<\mathrm{B} 2<\mathrm{B} 3<\mathrm{C} 3<\mathrm{C} 2<\mathrm{B} 4<\mathrm{C} 1$ の順で改善率の増加傾向が認められた.
表 4 Improvement rate of chewing strokes in the subjects based on the Eichner' $s$ classifications アイヒナー分類別の改善率

\begin{tabular}{|c|c|c|c|c|}
\hline \multicolumn{3}{|c|}{ Classifications } & \multicolumn{2}{|l|}{ Full classifications } \\
\hline \multirow{2}{*}{$\begin{array}{l}\text { A group } \\
(\mathrm{n}=20)\end{array}$} & \multirow{2}{*}{$19.1 \pm 16.6$} & \multirow{2}{*}{$\neg$} & A2 group $(n=16)$ & $22.5 \pm 16.1$ \\
\hline & & & A3 group $(n=4)$ & $5.4 \pm 11.2$ \\
\hline \multirow{4}{*}{$\begin{array}{l}\text { B group } \\
(\mathrm{n}=76)\end{array}$} & \multirow{4}{*}{\multicolumn{2}{|c|}{$25.4 \pm 16.4$}} & B 1 group $(n=17)$ & $16.1 \pm 16.8$ \\
\hline & & & B2 group $(n=17)$ & $23.1 \pm 13.7$ \\
\hline & & & B3 group $(n=20)$ & $28.3 \pm 15.7$ \\
\hline & & & B 4 group $(n=22)$ & $32.0 \pm 15.9$ \\
\hline \multirow{3}{*}{$\begin{array}{l}\text { C group } \\
(\mathrm{n}=29)\end{array}$} & \multirow{3}{*}{\multicolumn{2}{|c|}{$32.1 \pm 15.0$}} & C 1 group $(n=10)$ & $32.9 \pm 18.2$ \\
\hline & & & C2 group $(n=15)$ & $31.8 \pm 14.8$ \\
\hline & & & C 3 group $(n=4)$ & $31.6 \pm 8.9$ \\
\hline Total & & & $\mathrm{n}=125$ & $26.0 \pm 16.5$ \\
\hline ANOVA & $\mathrm{p}=0.0212$ & & & $p=0.0006$ \\
\hline
\end{tabular}

\section{IV. 考 察}

\section{1. 研究方法について}

補緅治療の評価を行う際には, 装着した義歯の機能 評価が簡便に行えることが望ましいことはいうまでも ない，本研究で使用した咀嚼回数計測法 ${ }^{12)}$ は義歯の 機能評価を簡便に行うのに適した評価法であるが，そ の臨床評価は十分ではない，そこで大学病院でメンテ ナンスを受けている義歯装着者を対象として臨床評価 を試みた。

1）被検者について

本研究で義歯装着効果の評価を行った被検者は, 新 潟大学医歯学総合病院義歯 (入れ歯) 診療室において, 補緅専門医により定期的なメンテナンスを受けている 義歯装着者であるため, 要治療部が存在せず, 装着義 歯に専門医が診て考えうる限り問題が存在していない 被検者である.

2）被検食品について

嚥下直前の食塊形成には, 食物が必要十分に粉砕さ れ, 歯列舌側の口腔内に存在し, 必要量の唾液分泌 ${ }^{16)}$ が要件となってくる。これらの要件が満たされると蟮

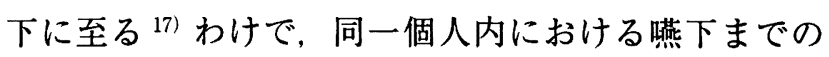
咀嚼回数は再現性の高い定量的数值である ${ }^{18)}$ 。この ような観点から唾液と混和されて食塊を形成し易い性 状を持つ食物の初回嚥下までの咀嚼回数は, その個人 の食塊形成能力を表す 1 つの評価值となると考えられ る。 
3）嚥下および咀嚼回数の判定について

武川ら ${ }^{13)}$ は唾液嚥下時の诶頭の動きを, 皮䖉上か ら視診, 触診により確認できるか否かという指標に基 づき，被検者 17 名を 3 群に分類し，筋電図，喉頭運 動および讌下音から嚥下の判定についての検討を行っ ている，それによると，視診，触診両者においても唾 液嚥下時の喉頭の動きが判定不能である場合は非常に 嚥下認識率が低くなるが, 視診, 触診両者の判定が可 能な場合は $100 \%$ の嚥下認識率を認めたとの報告を 行っている.

本研究で咀嚼回数計測法の的中度の検討を行った被 検者は, 唾液嚥下時の喉頭の動きを皮膚上より視診, 触診により確認できることの判定を行っているため, 初回嶼下時の判定精度は高いものと考えられる。 その ため, 今回の成人男子 5 名に扔ける筋電図学的な初回 嚥下までの咀嚼回数のデータと目視による初回嚥下ま での咀鮁回数のデータとから求めた的中度 $0.98 \pm 0.02$ は，観察者の目視によった咀嚼回数の測定が非常に高 い精度であることを示した.

このことより，義歯装着効果の評価においては挙手 による認識嚥下およびオトガイ部の動きを観察するこ とにより, 初回嚥下までの咀嚼回数を判定した.

4) 回数差と改善率について

河村ら ${ }^{18)}$ は，同一量で同一食品を恸取した時の咀 嚼回数 (嚥下閾) は被検者ごとに差違が認められるが, 各被検者においてほほ一定であると報告している。こ のことより，嚥下閥の影響を可及的に減じるために各 個人それぞれの義歯装着・非装着の初回嚥下までの咀 嚼回数の差である回数差の指標のみでなく，回数差を 各被検者ごとの初回嚥下までの咀嚼回数 (嚥下闇) で 除した值である改善率の指標を用いて，相対評価を試 みた。

\section{2. 義歯装着効果について}

1）アイヒナー 3 群における義歯非装着時咀嚼回数 について

義歯非装着時咀嚼回数の平均値による比較の結果は 表 2 に示す様にアイヒナー A 群 $<\mathrm{B}$ 群 $<\mathrm{C}$ 群の順で 咀嚼回数の増加が認められ, 多重比較検定によりアイ ヒナー A 群と C 群間で有意差を認めた. Kawamura ら ${ }^{19)}$ はピーナッッを用いて大臼歯欠損者の咀嚼回数 が，健常者と比較して多いことを報告しており，本研
究において用いた煎餅の咀夁においても，咬合支持の 減少により咀嚼回数の増加が認められ，同様の結果で あった．多重比較検定によりアイヒナー A 群と C 群 間で有意差を認めたことからも明らかなように，咬合 支持の有無が咀嚼能力に大きな影響を与えていると考 えられる.

2）アイヒナー 3 群における義歯装着時咀嚼回数に ついて

義歯装着時咀嚼回数の平均値による比較の結果は表 2 に示す様に A 群 35.6 回, B 群 34.7 回, C 群 37.7 回 とほとんど差を認めず, 3 群間で有意差も認めなかっ た. このことは, 多数歯欠損者である少数咬合支持域 保有者群と少数歯欠損者である多数咬合支持域保有者 群間で義歯補緅治療により咀嚼回数に差が認められな くなったことを意味しており，可撤性有床義歯欠損補 緅の有用性を示していると考えられる.

3）回数差について

（1）義歯装着により咀嚼回数が減少しない被検者に ついて

全被検者のうち $4 \%$ (125名中 5 名)が義歯装着によっ て咀嚼回数が減少しなかった。そのうち増加した被検 者は 3 名（アイヒナー $\mathrm{A} 2$ 群, $\mathrm{A} 3$ 群, B1 群の各 1 名), 変化しない被検者が 2 名（アイヒナー $\mathrm{A} 2$ 群, $\mathrm{B} 1$ 群 の各 1 名）存在した. A 群が 3 名, B 群とくに B1 群 から 2 名と全被験者 125 名中欠損の小さい被検者のみ に集中した。このことは，本評価法は多因子影響下の 嚥下閾を評価の指標としているため, 口胿内状況や補 緅処置の構造等の他の因子による影響により少数欠損 補緅処置の効果が現れにくかったことが原因と考えら れ，今後さらに追求していかなければならない課題で あると考えている.

（2）アイヒナー分類における評価值について

アイヒナー A 群, B 群, C 群それぞれにおいて義 歯装着により有意に咀嚼回数の減少が認められたＡ 群 $(\mathrm{p}=0.0011)$ に対して $\mathrm{B}$ 群・ $\mathrm{C}$ 群 $(\mathrm{p}<0.0001)$ にお いては特にその傾向が大きかった(表 2$)$.このことは, アイヒナーB・C 群などの欠損がある程度大きな群に なるほど, 義歯装着により咀嚼が行いやすくなり咀嚼 能力が高くなったことを示唆していると考えられる.

また, 表 3 に示すようにアイヒナー詳細分類の平均 值の比較により，一部の例外は認められるものの咬合 支持の減少に伴い回数差の増加を認めている. このこ 
とからも, 咬合支持数（咪みあう歯の組み合わせの数） が食物の咀翾し易さに影響する大きな要因になってい ることが示された。

4) 改善率について

（1）アイヒナー分類における評価値について

表 4 に示す様にアイヒナーA 群，B 群，C 群の順 に咬合支持域数が減少していくと，義歯装着による改 善率は有意に向上している．この結果は咬合支持域の 減少に伴い, 補緅歯数も増加している症例において, 義歯による補緅処置が, 咀嚼能力の向上に大きく寄与 していることを示している.

また，同じく表 4 に示すようにアイヒナー詳細分類 の平均値の比較により，一部の例外は認められるもの の咬合支持の減少に伴い改善率の増加を認めている. このことからも咬合支持域数（噛みあう歯の組み合わ せの数）が食物の咀嚼し易さに影響する大きな要因に なっていることが示された.

これまで, 咀嚼能力の評価として咀噮回数を検討し た報告は少ないが, Gunne ${ }^{20)}$ は，ゼラチンを被検食 品として本研究と同じように咀嚼回数を計測する方法 で下顎両側遊離端義歯製作前後について咀翾能力を分 析し，義歯装着による改善率は $16.2 \%$ であったと報告 している. 本研究の改善率は, B2 群が $23.1 \%$ B3 群

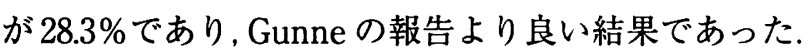

5）回数差と改善率の比較について

本咀夁回数計測法は補綴歯数の影響が少なく，義歯 を含めた全歯列で十分に咀嚼可能になると，アイヒ ナー3群間で咀嚼回数に差が認められなかった(表 2$)$. また, 3 群内で義歯非装着時咀嚼回数から義歯装着時 咀嚼回数を引いた值である回数差においてアイヒナー C 群， B 群，A 群の順で大きな差が認められたが（表 3), 義歯非装着時咀嚼回数も同じ傾向で差が認められ た. よって同じ傾向の值を同じ傾向の值で除している ため，改善率において 3 群間では回数差に比べ有意差 が出にくくなったものと考えられる．また，本被検者 群は大学病院義歯 (入れ歯) 診療室で義歯新製後 3 ヶ 月以上経過しメンテナンスに移行した被検者であり, 義歯が良好に口胿内で機能している群であると考えら れるため, 義歯装着の効果に義歯の大小での差が出難 かったと推察される. 今後様々な条件の被検者群を設 定し大数による更なるデー夕収集に努める所存であ る.

\section{3. 本計測法の特性について}

過去の咀嚼能率測定を行った研究はいずれも非吸水 性硬性食品（試料）を使用しており，歯牙欠損が広範 に及ぶ被検者の義歯非装着時の測定が困難であった. そのため, そのような粉砕能力評価を行なう咀嚼能力 評価法においては，必然的に，義歯補緅治療効果を調 べる場合, 同一被検者の義歯装着, 非装着についてで はなく義歯装着被検者と健全歯列者との比較を行って いる. しかしながら，本研究に用いた煎餅は無歯顎患 者が義歯非装着で咀嚼することが可能である程，吸水 して軟質な性状に変化し，いずれの被検者でも義歯装 着, 非装着時の比較が可能であった.このことは, 本 測定法に用いた煎餅は通常の粉砕による食塊形成と異 なり, 粉砕過程が短く, 唾液と混和して食塊形成に早 期に移行するためであると考えられる.

ヒトはどんなに細かい粉砕粒子であっても乾燥状態 であると嚥下に至ることはできず，必要量の唾液との 混和により形成された食塊（bolus）が嚥下間以下の表 面性状に到達することで嚥下が誘発される ${ }^{17)}$. この ことから本評価法で表される数值は食塊形成能力を表 す定量的評価値 ${ }^{22)}$ であると考えられる.

また生体の生理的活動において，嚥下を前提としな い咀嚼運動は存在せず，その点からも本計測法は被検 食品（試料）を口腔外に回収することを前提としない 計測法であるため, 食物認識, 食物䎼取, 咀嚼, 食塊 形成，嚥下といった一連の生理運動の中で評価可能な 方法であり，他の評価法と異なる優れた点である.

\section{V. 結 論}

我々が考案した咀嚼回数計測法を用いた補綴治療の 評価を行った研究から以下のことが明らかとなった。

1. 咀嚼回数計測法の的中度は $0.98 \pm 0.02$ であった.

2. 義歯非装着時の咀嚼回数にアイヒナーA 群, B 群, C 群間で有意差が認められた。

3. 義歯装着時の咀嚼回数にアイヒナー A 群, B 群, C 群間で有意差は認められなかった.

4. 義歯の装着により，アイヒナー A， B，C群の 被検者において咀嚼回数の有意な減少が認められた. その傾向はアイヒナー B，C 群において特に大きかっ た. 
5. 被検者の欠損がアイヒナー A 群, B 群, C 群と 大きくなるに従い, 回数差, 改善率の増加が認められ, 咬合支持域数が減少するほど義歯装着効果の大きいこ とが明らかとなった.

6. 回数差はアイヒナーA 群 8.4 回, B 群 13.4 回, C 群 20.3 回であった.

7. 改善率はアイヒナー A 群 $19.1 \%$, B 群 $25.4 \%$, C 群 $32.1 \%$ であった.

\section{文献}

1）厚生省健康政策局歯科保健課編. 平成 11 年歯科疾患実 態調査報告一厚生省健康政策局調查 28 133-135, 東京: 口腔保健協会, 2001.

2) Manly RS, Braley LC : Masticatory performance and efficiency. J Dent Res 29 : 448-462, 1950.

3) Ohara A,Tsukiyama Y, Ogawa $T$ et al. A simplified sieve method for determining masticatory performance using hydrocolloid material. J Oral Rehabil $30: 927-$ 935, 2003.

4）梅原亜紀，野首孝祠，安井 栄ほ力，全部床義歯装着患 者において試験用グミゼリーを用いる咀嚼能率診査法の 改良. 補綴誌 $41: 850-855,1997$.

5）増田元三郎. A T P 顆粒剤を用いた吸光度法による新し い咀喂能力測定法 第 3 報 上顎義顎装着者と健全歯列 者, 総義歯装着者の咀嚼能力の検討. 日口科誌 32 : 498-508, 1983.

6）平野滋三, 高橋保樹, 渡辺一騎ほか. 色変わりチューイ ンガムによる義歯装着者の咀嚼能力測定の試み、補緅誌 $45: 730-736,2001$

7) Sato H, Fueki K. Sueda S et al. A new and simple method for evaluating masticatory function using newly developed artificial test food. J Oral Rehabil 30 : 68-73, 2003.

8）山本為之. 絵義歯臼歯部人工歯の配列について（2）特に反対咬合について一. 補緅臨床 $5: 395-400,1972$.

9) Kapur KK : Studies of biologic parameters for denture design. Part I . Comparison of masseter muscle activity during chewing of crisp and soggy wafers in denture and dentition groups. J Prosthet Dent $33: 242$ $-249,1975$

10) Woelfel JB, Hickey JC, Allison ML. Effect of posterior tooth form on jaw and denture movement. J Prosthet Dent $12: 922-939,1962$.

11）加藤一誠，河野正司，新井映子ほか. Videofluorographyの支援による有床義歯補緅治療. 補綴誌 $44: 625-$ $632,2000$.

12）本間 済, 河野正司, 武川友紀ほか. 煎餅を用いた食塊 形成能力からみた咀嚼能力評価法. 顎機能誌 $10: 151-$ 160, 2004.

13）武川友紀, 河野正司, 岩片信吾ほか. 嚥下行動の認識に ついての検討. 顎機能誌 $7: 110-111,2001$.

14）相澤秀夫, 佐々木啓一, 渡辺 誠. 自発嚥下時における 顎筋, 舌骨筋群活動の時系列的検討. 補緅誌 $45: 582-$ 591，2001.

15）Körber K（田端恒雄, 河野正司, 福島俊士). Zahnärztliche Prothetik（ケルバーの補緅学 第 1 巻 135-139, 東京：クインテッセンス出版，1982），1975.

16）楠元正一郎. 食物咀嚼におよほす唾液分泌量の影響一食 塊水分量と嬹下閾一。明海大歯誌 $28: 40-48,1999$.

17) Prinz JF, Lucas PW. Swallow threshold in human mastication. Arch Oral Biol 40 : 401-403, 1995.

18）河村洋二郎, 塚本周作. 咀噮習慣形成機序に関する実験 的研究 I 食物粉砕度と嚥下間. 歯界展望 $16: 1039-$ 1046, 1959 .

19) Kawamura $Y$, Nobuhara M. Studies on masticatory function II. The swallowing threshold of persons with normal occlusion and malocclusion. Med J Osaka Univ 8 : 241-246, 1957

20) Gunne HS. The effect of removable patial dentures on mastication and dietary intake. Acta Odontol Scand $43: 269-278,1985$.

著者連絡先：本間 済

干 951-8514 新潟市学校町通 2-5274

TEL : 025-227-2894

FAX : 025-229-3454

E-mail : wataru@dent.niigata-u.ac.jp 


\title{
Evaluation of Prosthetic Treatment Using Number of Chewing Strokes until Swallowing of Water Absorbing Rice Crackers
}

\author{
Honma Wataru, Kohno Shoji, Sakurai Naoki and Kobayashi Hiroshi
}

Division of Removable Prosthodontics Niigata University Graduate School of Medical and Dental Sciences

J Jpn Prosthodont Soc : $50: 219-227,2006$

\section{ABSTRACT}

Purpose : Various methods of evaluating the ability of mastication have been reported, most of which involve evaluating of the ability to comminute foods. In this study, a new method of evaluating the ability of mastication focusing on bolus formation was applied to denture wearers.

Methods : One hundred and twenty-five subjects (71 males and 54 females) using removable dentures and receiving follow-up in the Niigata University Hospital were selected. This group was categorized by Eichner's classification, and investigated for the effect of prosthetic treatment by counting the number of chewing strokes until the first swallow of rice crackers.

Results : It was clarified that the number of chewing strokes until the first swallow counted by visual observation agreed well with the number of chewing strokes counted by electromyogram wave of masseter muscle, laryngeal motion, and swallowing sound, as a preparatory experiment. Using the method of counting chewing strokes by visual observation, the effect of prosthetic treatment was evaluated, and the results were as follows. 1) There is a significant difference in the number of chewing strokes without dentures between the Eichner A group, B group, and C group. 2) There was no significant difference in the number of chewing strokes with dentures among the three groups. 3) A significant decrease in the number of chewing strokes was proven by the use of removable dentures. 4) Both the improvement rate of chewing strokes (the ratio of the number of chewing strokes with dentures until the first swallow to that without dentures) and the difference of chewing strokes increased significantly in the order of Eichner A, B, and C.

Conclusion : It was clarified that the effect of prosthetic treatment can be quantitatively evaluated by counting the chewing strokes of rice cracker. Moreover, it was suggested that the condition of prosthetic treatment can be evaluated by analyzing the improvement rate of chewing strokes.

\section{Key Words}

number of chewing strokes, ability of mastication, effect of removable prosthetic treatment, improvement rate of chewing strokes 